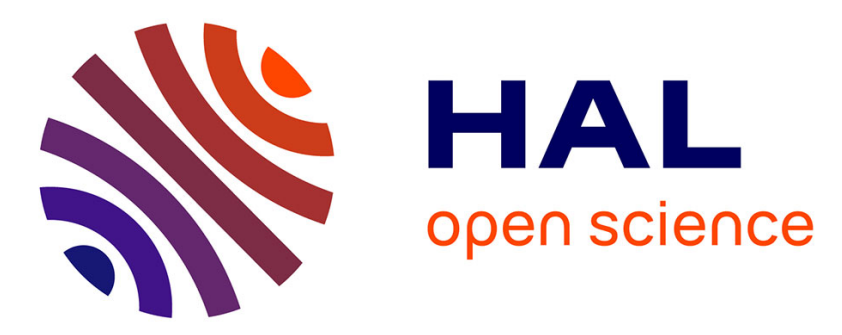

\title{
The surfactant addition effect in the elaboration of electrodepositated NiP-SiC composite coatings
}

Célia de Fraga Malfatti, Hugo Marcelo Veit, Tiago Lemos Menezes, Jane

Zoppas Ferreira, J.S. Rodriguês, Jean-Pierre Bonino

\section{To cite this version:}

Célia de Fraga Malfatti, Hugo Marcelo Veit, Tiago Lemos Menezes, Jane Zoppas Ferreira, J.S. Rodriguês, et al.. The surfactant addition effect in the elaboration of electrodepositated NiP$\mathrm{SiC}$ composite coatings. Surface and Coatings Technology, 2007, vol. 201, pp. 6318-6324. 10.1016/j.surfcoat.2006.11.040 . hal-00807804

\section{HAL Id: hal-00807804 https://hal.science/hal-00807804}

Submitted on 4 Apr 2013

HAL is a multi-disciplinary open access archive for the deposit and dissemination of scientific research documents, whether they are published or not. The documents may come from teaching and research institutions in France or abroad, or from public or private research centers.
L'archive ouverte pluridisciplinaire HAL, est destinée au dépôt et à la diffusion de documents scientifiques de niveau recherche, publiés ou non, émanant des établissements d'enseignement et de recherche français ou étrangers, des laboratoires publics ou privés. 


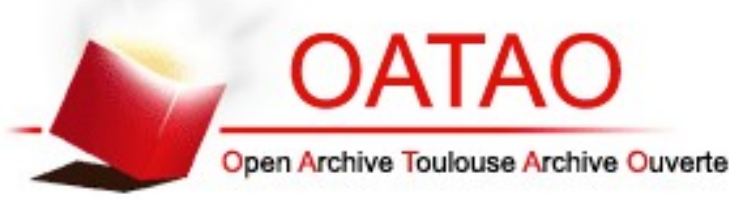

\section{Open Archive Toulouse Archive Ouverte (OATAO)}

OATAO is an open access repository that collects the work of Toulouse researchers and makes it freely available over the web where possible.

This is an author-deposited version published in: http://oatao.univ-toulouse.fr/ Eprints ID : 2458

To link to this article :

URL : http://dx.doi.org/10.1016/j.surfcoat.2006.11.040

To cite this version : Malfatti, C.F and Veit, H.M. and Menezes, T.L. and Zoppas Ferreira, J and Rodriguês, J.S. and Bonino, Jean-Pierre ( 2007) The surfactant addition effect in the elaboration of electrodepositated NiP-SiC composite coatings. Surface and Coatings Technology, vol. 201 (n 14). pp. 6318-6324. ISSN 0257-8972

Any correspondence concerning this service should be sent to the repository administrator:staff-oatao@inp-toulouse.fr 


\title{
The surfactant addition effect in the elaboration of electrodepositated NiP-SiC composite coatings
}

\author{
C.F. Malfatti ${ }^{\text {a,b,* }}$, H.M. Veit ${ }^{\text {a,b }}$, T.L. Menezes ${ }^{\text {b }}$, J. Zoppas Ferreira ${ }^{\text {b }}$, J.S. Rodriguês ${ }^{\text {b }}$, J.-P. Bonino ${ }^{c}$ \\ ${ }^{\text {a } I C E T-F e e v a l e, ~ R S ~ 239, ~ 2755 . ~ Z i p ~ C o d e: ~ 93352-000, ~ N o v o ~ H a m b u r g o, ~ R S ~ B r a z i l ~}$ \\ ${ }^{\mathrm{b}}$ LACOR-PPGEM, Universidade Federal do Rio Grande do Sul,Porto Alegre RS Brazil \\ ${ }^{\mathrm{c}}$ CIRIMAT-UMR CNRS no. 5085, Université Paul Sabatier, Toulouse, France
}

\begin{abstract}
In this work, NiP-SiC composite coatings were prepared by electrodeposition from a plating bath containing $\mathrm{NiSO}_{4} \cdot 6 \mathrm{H}_{2} \mathrm{O} ; \mathrm{NiCl}_{2} \cdot 6 \mathrm{H}_{2} \mathrm{O} ; \mathrm{H}_{3} \mathrm{PO}_{3}$; $\mathrm{H}_{3} \mathrm{PO}_{4} ; \mathrm{Na}_{2} \mathrm{SO}_{4}$ and $\mathrm{SiC}$ particles (average diameter of $600 \mathrm{~nm}$ ) in suspension. Anionic surfactant (SDS - sodium dodecyl sulfate, $\mathrm{CH}_{3}$ $\left(\mathrm{CH}_{2}\right)_{11} \mathrm{SO}_{4} \mathrm{Na}$ ) or cationic surfactant (CTAHS - cetyltrimethylammonium hidrogensulfate, $\mathrm{C}_{19} \mathrm{H}_{43} \mathrm{NO}_{4} \mathrm{~S}$ ) were also added to this suspension. The number of incorporated particles by area unit $\left(\alpha_{\mathrm{np} / \mathrm{A}}\right)$ was evaluated by image analysis of micrographs obtained by scanning electron microscopy (SEM). It was observed that organic additive addition influences the incorporated SiC particles rate on the metallic matrix. Addition of organic additives such as SDS or CTAHS modifies the characteristic of suspensions. Depending on particle size organic additive addition can change the number of incorporated particles in deposits during growth of the matrix. Decrease of the incorporated particle amount with the increase of particle size was verified. The selective incorporation process is associated to the presence of organic additive and it was not dependent on surfactant charge.
\end{abstract}

Keywords: NiP-SiC composite coatings; Anionic surfactant; Cationic surfactant

\section{Introduction}

The present work has a strong industrial appeal, which consists in research of solutions to improve performance of components in general in terms of electrochemical behavior and their mechanic properties, ceasing to use coatings that use polluting processes.

The replacement of processes such as hard chromium is a worldwide reality. European Union laws [1] determine that since July 1st, 2006 new eletrical and eletronic equipment put on the market should not contain: PBB (polybrominated biphenyls), PBDE (polybrominated diphenys ethers), lead, mercury, cadmium, or hexavalent chromium, which indicate the future prohibition of several applications in other areas.

However, the inherent characteristics of hard chromium coatings allow it to remain in use although this coating has

\footnotetext{
* Corresponding author. Tel.: +55 51 33169432; fax: +55 5135868800 .

E-mail addresses: malfatti@feevale.br,malfattimc@gmail.com (C.F. Malfatti).
}

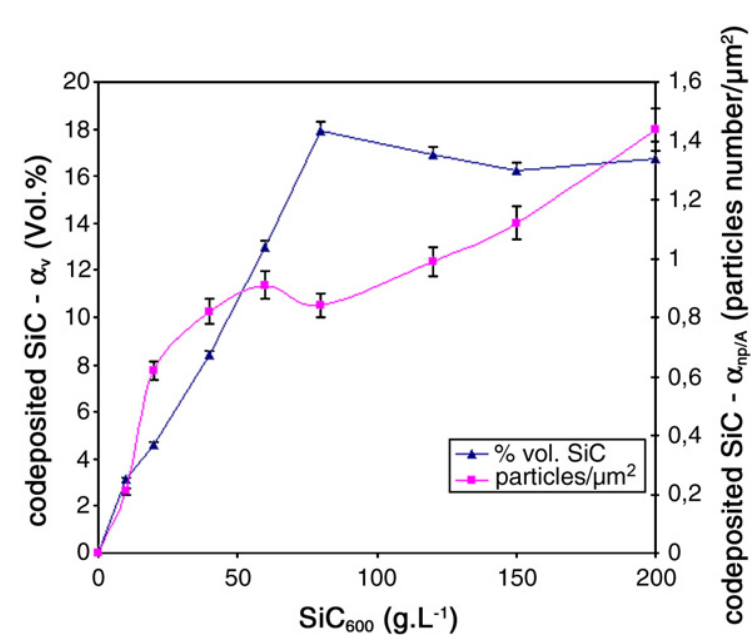

Fig. 1. Incorporation rate evolution, expressed as volume percent of incorporated particles $\left(\alpha_{\mathrm{v}}\right)$ and particle number by area unit $\left(\alpha_{\mathrm{np} / \mathrm{A}}\right)$ as function of $\mathrm{SiC}$ concentration in the electrolyte to $\mathrm{H}_{3} \mathrm{PO}_{3} 20 \mathrm{~g} \mathrm{~L}^{-1}$. 
electrolytic solutions based on hexavalent chromium, which is a dangerous solution for the environment because of the high solubility of Chromium VI.

A

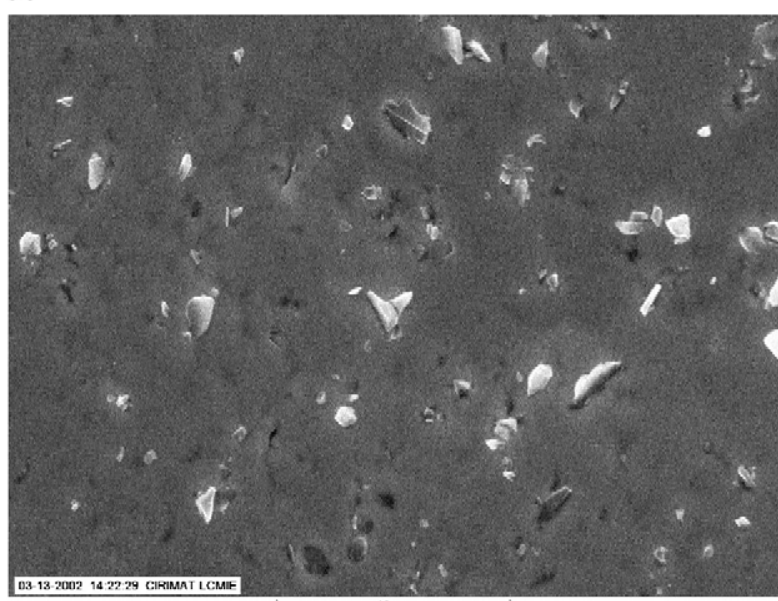

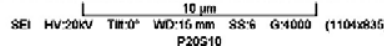

C



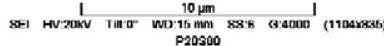

E

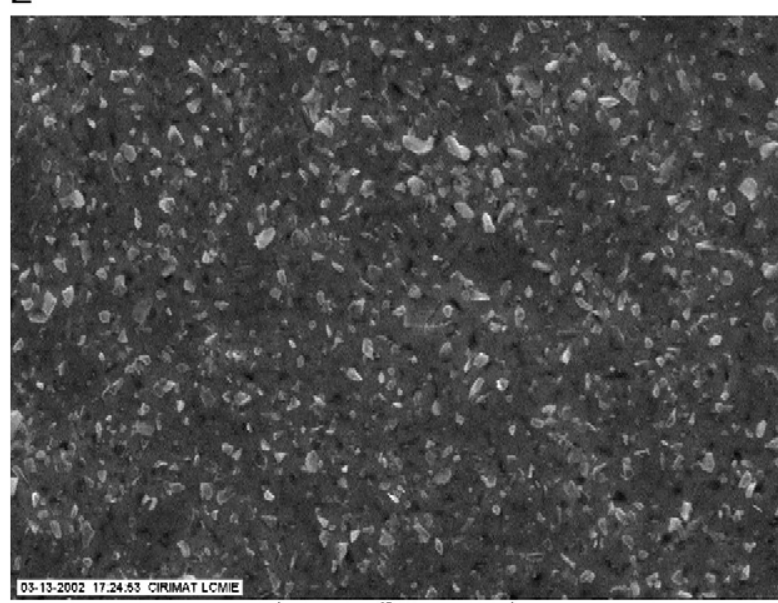

8E1 HV.20kV Till.6"
Chromium coatings have wide application in industry because they promote decorative characteristics (decorative chromium), or high hardness characteristics (hard chromium) [2] because

B

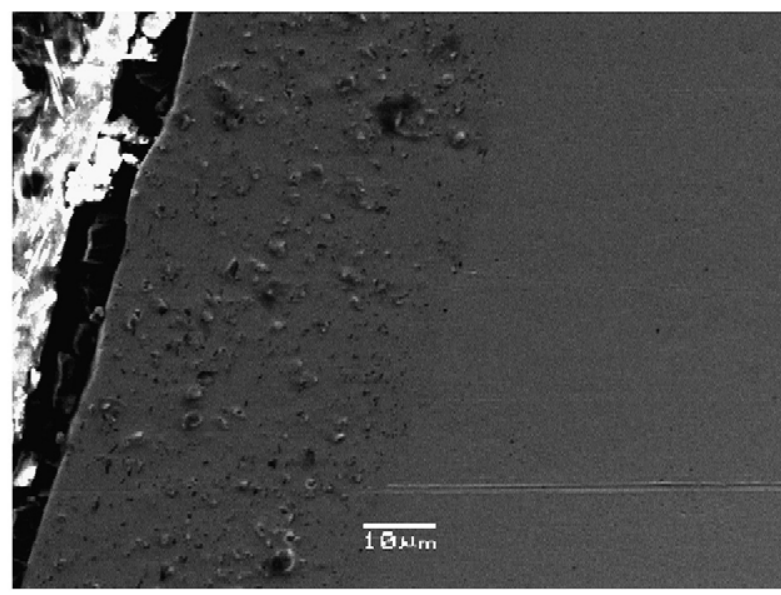

D

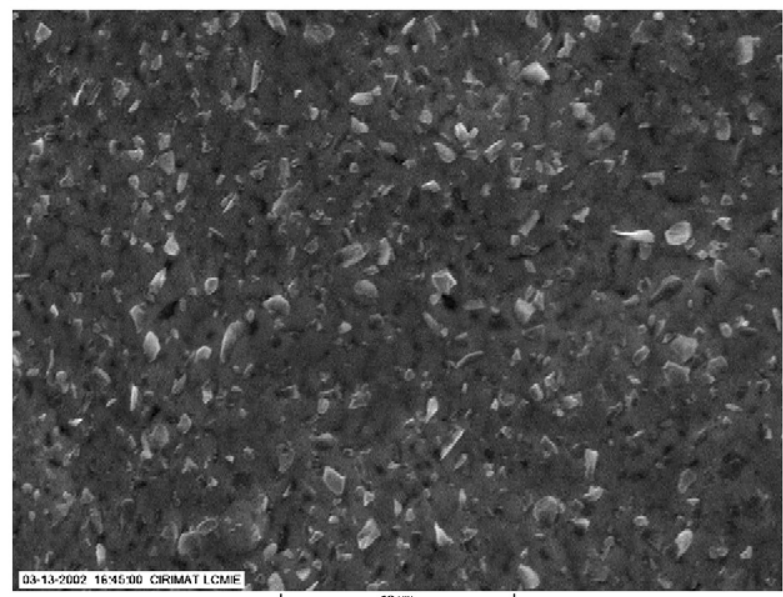

SCI HN:20kV Til:0.0

F

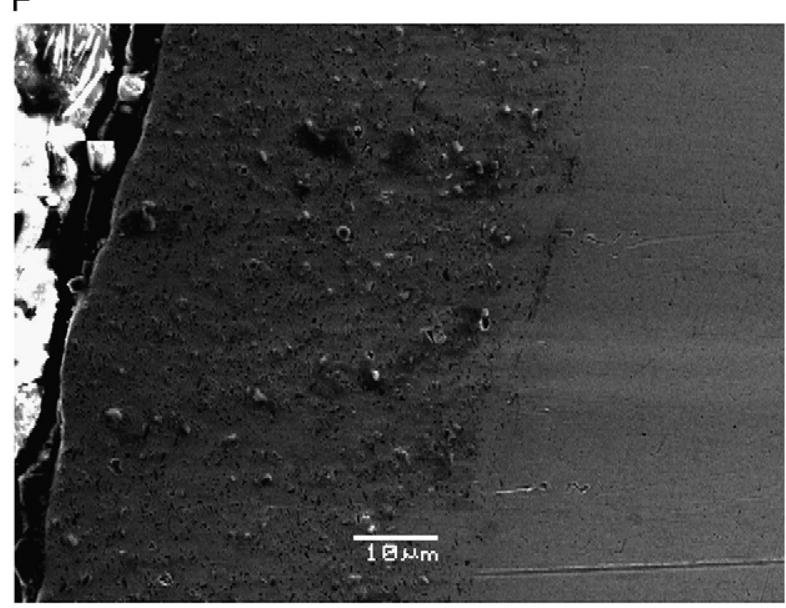

Fig. 2. SEM micrographs of composite NiP-SiC coating obtained from bath with different concentration of $\mathrm{SiC}$ particles $\left(20 \mathrm{~g} \mathrm{~L}^{-1} \mathrm{H}_{3} \mathrm{PO}_{3}\right.$ in electrolyte): A) $10 \mathrm{~g} \mathrm{~L}$ $\mathrm{SiC}$; B) $10 \mathrm{~g} \mathrm{~L}^{-1} \mathrm{SiC}$ (cross-section); C) $80 \mathrm{~g} \mathrm{~L}^{-1} \mathrm{SiC}$; D) $120 \mathrm{~g} \mathrm{~L}^{-1} \mathrm{SiC}$; E) $200 \mathrm{~g} \mathrm{~L}^{-1} \mathrm{SiC}$; F) $200 \mathrm{~g} \mathrm{~L}^{-1} \mathrm{SiC}$ (cross-section). 
chromium has a very high hardness, approximately between $900 \mathrm{Hv}$ and $1000 \mathrm{Hv}$. Nevertheless, besides its high toxicity, neutralizing effluents from the chromium deposition process is difficult, because it requires a reduction step before precipitation.

There are many other coatings used to increase the wear resistance of the surfaces, including processes as plasma projection, application of different diffusion heat treatments such as cementation and nitrating, deposition or electrodeposition of metals, and metallic alloys with high hardness or whose hardness could be modified by subsequently heat treatment, and composite coatings in metallic matrix.

The electrodeposition of metals and metallic alloys has been widely employed in industry to obtain coating, because it allows the use of less noble materials as substrates with excellent results. Thus, there is particular interest in electrodeposited metallic alloys, since this process allows obtaining layers with better mechanical and physical properties, besides a better corrosion resistance than layers made just of those individual metals. A big variety of binary metallic alloys can be obtained by electrodeposition, that being the most important aspect about zinc from the technological and economic point of view: tin, nickel, and noble metals alloys [3].

The technologies as PVD or nitration offer some limitations about the size of the samples and the cost of the initial investment, so other alternatives have been developed in recently researches regarding wet way processes and the elaboration of metal/particles composite coatings obtained chemical or electrochemically. The process consists in incorporating, during the electrodeposition process of a metal or metallic alloy, particles that were added to the electrolyte as a suspension [1,4-9]. Those processes offer the perspective of developing and transferring the fast technology and constitute a promising way to surface treatment.

This process, that for long was just curiosity in research laboratories, is a worldwide reality today. The composite coatings NiP-SiC successfully developed a few years ago at the automotive industry (PSA, Poeton, ...) can be mentioned as examples and, more recently, in countries such as England, France and Japan, the Bristol Aerojet societies, Poentonm Prazair, Snecma and Suzuki, the development of multifunction composite coatings to high temperature applications.

Recently, the development of lubricant composite coatings Ni-PTFE (with Teflon incorporation), NiCoCrAlY refractory deposits for high-temperature applications in aeronautics industries makes this subject even more captivating.

Comparatively to chromium coatings obtained from hexavalent chromium, effluents coming from the nickel coatingobtaining process have a conventional, more simplified treatment, and the processes called Clean Technologies, such as electrodialysis, may be successfully used, thus minimizing or even eliminating the residue produced in the process [10].

Nickel phosphorus coatings can be heat-treated, and, depending on the amount of phosphorus they may achieve hardness values higher than $1000 \mathrm{Hv}[11,12]$. There is also the possibility of NiP coatings with incorporated particles being heat-treated in order to achieve hardness and wear resistance higher than the other coatings, such as NiP without particles, or even NiP with particles, but not heat-treated.
As it has been verified in past studies [11,13] the particle presence in a metallic matrix increases the wear resistance of these composite coatings, which can achieve hardness and wear resistance higher than the same properties of hard chromium $[11,12]$ observed mass loss equal to hard chromium [14] for NiP-SiC (>15\%at.P) composite coatings.

Studies have been conducted with the main objective of characterizing these composite coatings about its physical, mechanical and tribological properties of the obtained layers $[11,12,15,16]$, as well as their corrosion resistance $[17,18]$.

Studies about the co-deposition mechanism have shown the importance and influence of cations and anions in the electrolytic solution, as well as the organic and inorganic additive effects in particle incorporation into composite coatings [19-22].

Usually, to avoid pitting formation during the electrodeposition process of NiP coatings elaboration, surfactants, such as sodium dodecyl sulfate (SDS - $\mathrm{CH}_{3}\left(\mathrm{CH}_{2}\right)_{11} \mathrm{SO}_{4} \mathrm{Na}$ ) are often added to electrolyte formulation. The same procedure can be used to composite coating elaboration. As it was mentioned before, studies in the literature distinguished an important influence of the surfactants over the amount and over the incorporated particle dispersion in the composite coating.

In this study, NiP-SiC composite coatings were elaborated from an electrolyte of nickel chlorite and sulfate, phosphoric and phosphorous acid (phosphorus precursor to constitute the matrix), and silicon carbide particles (medium average of $600 \mathrm{~nm}$ ) in suspension. In this solution surfactants anionic (SDS) or cationic (CTAHS - cetyltrimethylammonium hidrogensulfate $-\mathrm{C}_{19} \mathrm{H}_{43} \mathrm{NO}_{4} \mathrm{~S}$ ) were also added so as to study the influence of the surfactant addition, as well as charge influence over the amount of particles incorporated per area unit $\left(\alpha_{\mathrm{np} / \mathrm{A}}\right)$ in NiP-SiC composite coating.

\section{Experimental}

$\mathrm{NiP} / \mathrm{SiC}$ composite coatings, were prepared by electrodeposition from a Brenner [23] type plating bath containing $\mathrm{NiSO}_{4} \cdot 6 \mathrm{H}_{2} \mathrm{O}$ $210 \mathrm{~g} \mathrm{~L}^{-1} ; \mathrm{NiCl}_{2} \cdot 6 \mathrm{H}_{2} \mathrm{O} 60 \mathrm{~g} \mathrm{~L}^{-1} ; \mathrm{H}_{3} \mathrm{PO}_{3} 20 \mathrm{~g} \mathrm{~L}^{-1} ; \mathrm{Na}_{2} \mathrm{SO}_{4} 50 \mathrm{~g}$ $\mathrm{L}^{-1}$ and $0-200 \mathrm{~g} \mathrm{~L}^{-1}$ silicon carbide $(\mathrm{SiC})$ particles with a mean diameter of $600 \mathrm{~nm}$ and a large granulometric distribution (between 100 and $5000 \mathrm{~nm}$ ). Surfactants as SDS and CTAHS were also added to the suspension. The $\mathrm{pH}$ of the solution was 2 at $80^{\circ} \mathrm{C}$.

Grannulometry measurements of $\mathrm{SiC}$ particles were determined using a Malvern Mastersize 2000S apparatus.

Table 1

The mean area of embedded particles in composite NiP-SIC coatings

\begin{tabular}{|c|c|c|c|c|}
\hline \multirow{3}{*}{$\begin{array}{l}\mathrm{SiC} \text { concentration } \\
\text { in the electrolyte } \\
\left(\mathrm{g} \mathrm{L}^{-1}\right)\end{array}$} & \multicolumn{4}{|c|}{ Mean area of embedded particles $\left(\mu \mathrm{m}^{2}\right)$} \\
\hline & \multirow{2}{*}{$\begin{array}{l}\text { Without } \\
\text { surfactant }\end{array}$} & \multicolumn{2}{|l|}{ SDS } & \multirow{2}{*}{$\frac{\text { CTAHS }}{3.5 .10^{-4} \mathrm{M}}$} \\
\hline & & $1.7 .10^{-4} \mathrm{M}$ & $3.5 \cdot 10^{-4} \mathrm{M}$ & \\
\hline 10 & 0.337 & - & - & - \\
\hline 80 & 0.247 & 0.248 & 0.285 & \\
\hline 120 & 0.240 & - & - & 0.229 \\
\hline 200 & 0.168 & 0.215 & 0.190 & 0.215 \\
\hline
\end{tabular}

It is evaluated as function of the $\mathrm{SiC}$ concentration in suspension, and as function of different SDS and CTAHS concentrations in the electrolyte. 
The electrodeposition was carried out in a thermostatic cell $(140 \mathrm{~mL})$ where both static vertical electrodes were immersed. A combined stirring system (magnetic stirrer and vertical bar stirrer) allows keeping the particles in suspension and moving them towards the cathode. The substrate utilized was a copper $\operatorname{disk}\left(A=1.76 \mathrm{~cm}^{2}\right)$ and a nickel sheet $\left(A=4 \mathrm{~cm}^{2}\right)$ was used as a
A

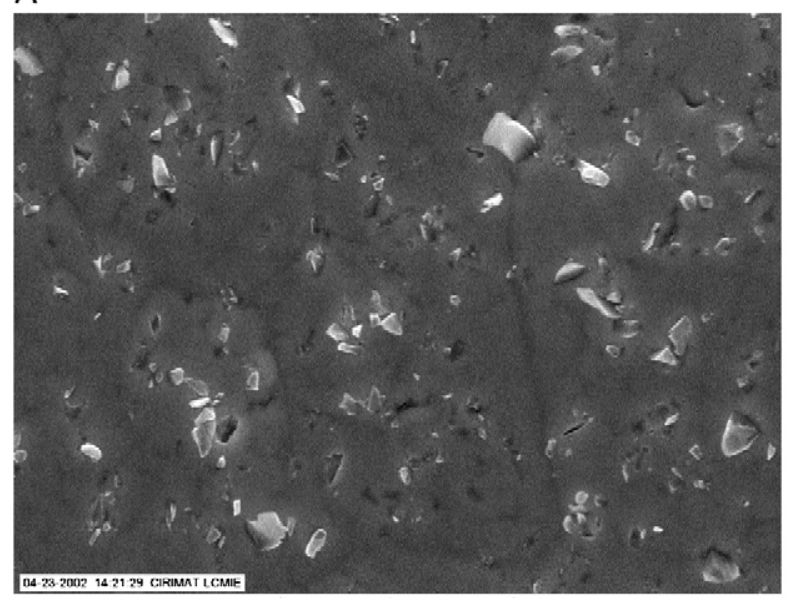

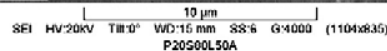

$\mathrm{C}$

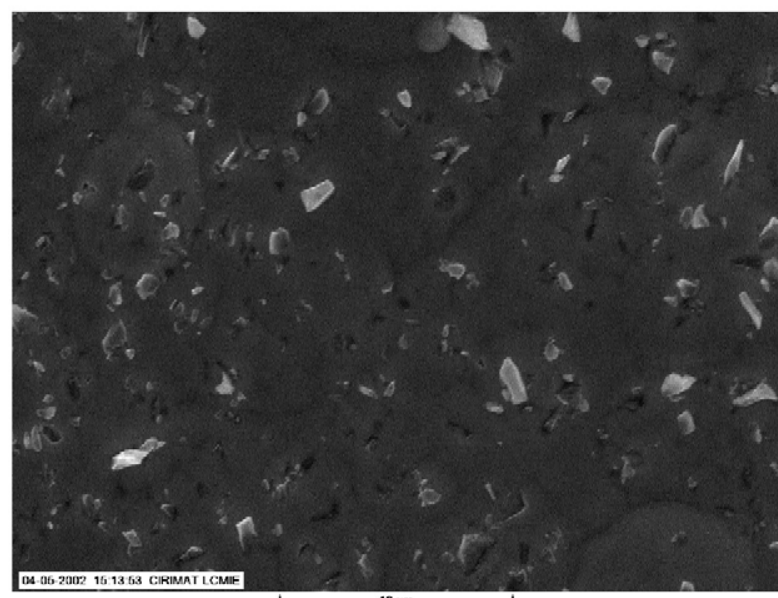

SEI HV:20hV Tili:-0.

E

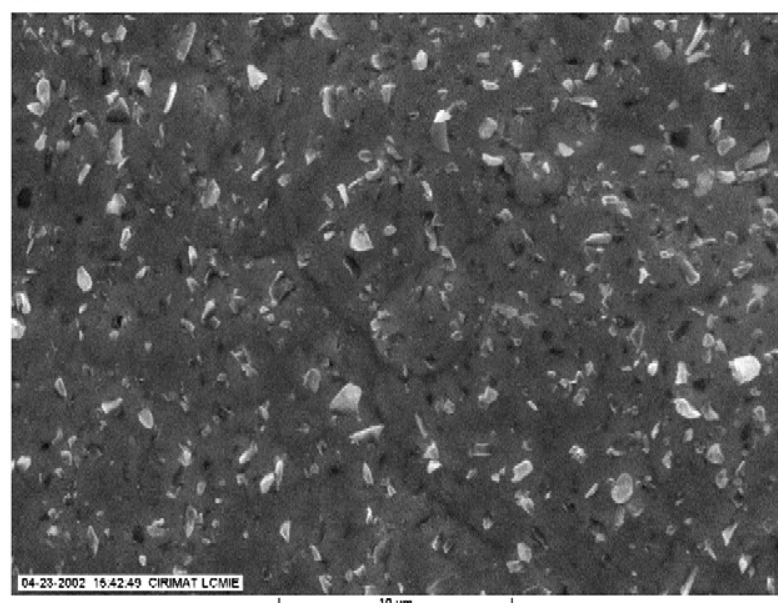

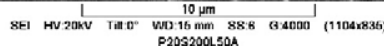

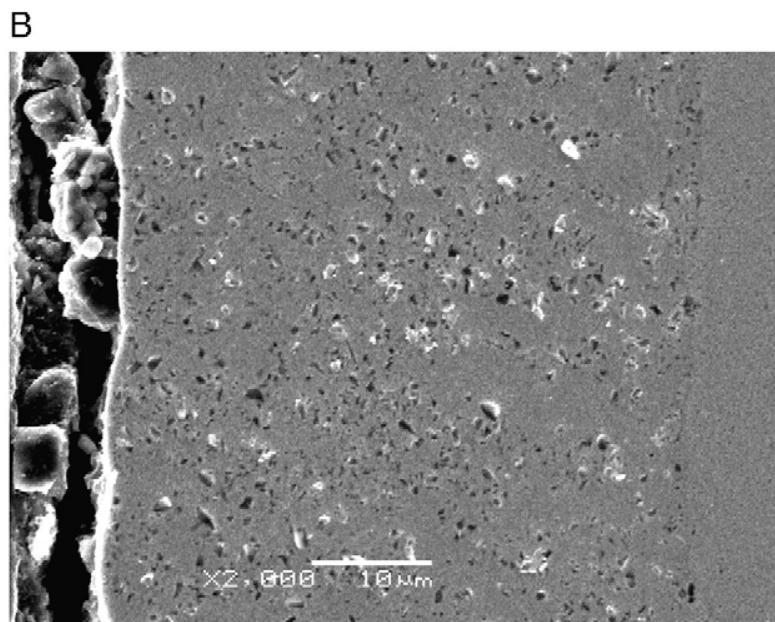

D

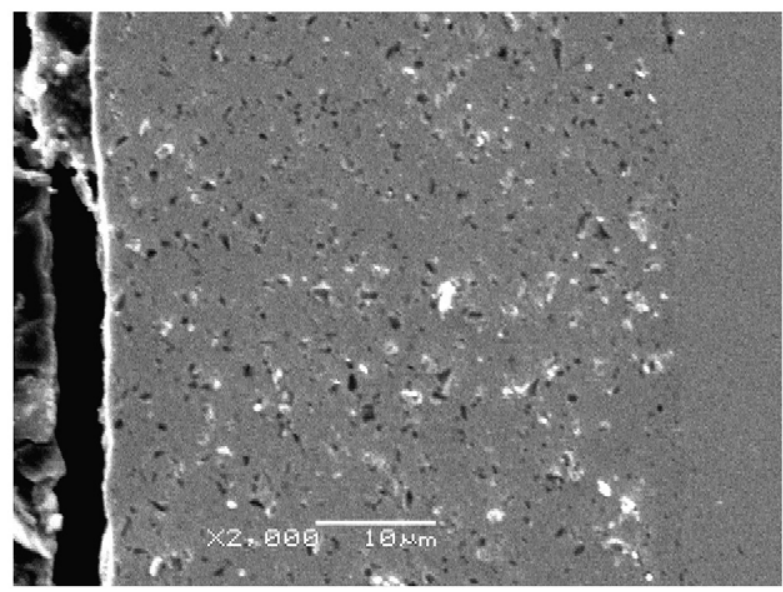

F

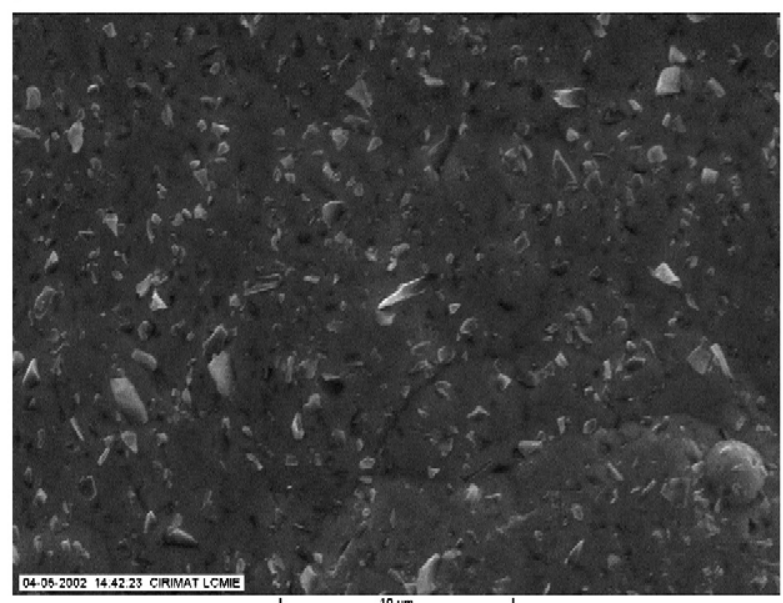

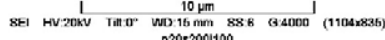

Fig. 3. Micrographs obtained by SEM: Effects of SDS concentrations in the electrolyte on Ni-P-SiC composite coatings: A) $80 \mathrm{~g} \mathrm{~L}{ }^{-1} \mathrm{SiC}_{\text {and }} 1.7 .10^{-4} \mathrm{M} \mathrm{SDS}$; B) $80 \mathrm{~g}$

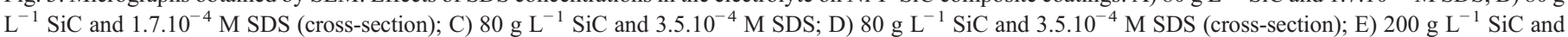
1.7.10 $0^{-4} \mathrm{M}$ SDS; F) $200 \mathrm{~g} \mathrm{~L}^{-1} \mathrm{SiC}$ and 3.5.10 $0^{-4} \mathrm{M}$ SDS. 


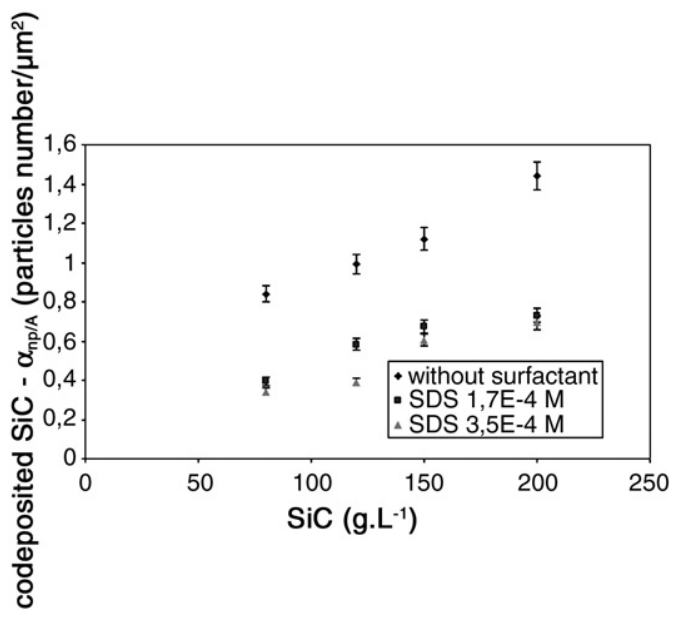

Fig. 4. Variation in number of incorporated particles per area unit $\left(\alpha_{\mathrm{np} / \mathrm{A}}\right)$ as a result of the $\mathrm{SiC}$ concentration in suspension to different SDS concentrations in the electrolyte.

soluble anode. The electrodeposition was carried out with a $0.1 \mathrm{~A} \mathrm{~cm}^{-2}$ current density, what resulted in $50 \mu \mathrm{m}$ thickness composite coatings (measured by optical microscopy crosssections). After electrodeposition, the specimens were cleaned by ultrasound for $2 \mathrm{~min}$.

The number of incorporated particles by area unit $\left(\alpha_{\mathrm{np} / \mathrm{A}}\right)$ was evaluated by image analysis (with Imagetools software) of micrographs obtained by Scanning Electron Microscopy (SEM) JEOL JSM 6400.

The volume percentage of silicon carbide incorporated into the metallic matrix $\left(\alpha_{v}\right)$ and the $P$ content into the metallic matrix NiP and into the composite Ni-P-SiC coatings were determined from chemical analysis of the coatings composition by Energy Dispersion Spectroscopy (EDS), with the SEM JEOL JSM 6400.

\section{Results and discussion}

\subsection{Effect of the SiC concentration in the suspension}

Several authors [24,25], have already shown the influence of the particle concentration in suspension over the incorporation rate of the particles in the metallic matrix.

Other authors [26] have already observed, the elaboration of NiP-SiC composite coatings, saturation of the incorporation phenomenon from $100 \mathrm{~g} \mathrm{~L}^{-1} \mathrm{SiC}$ concentration in suspension.

It was verified that, as shown in Fig. 1, the incorporated particle in volumetric fraction $\left(\alpha_{\mathrm{v}}\right)$, evaluated by chemical analysis, increased very fast, starting from low suspension concentration, then reaching a plateau (which shows the saturation of the incorporation phenomena), agreeing with the results reported in literature [26]. However, the incorporated particle number by coating area unit $\left(\alpha_{\mathrm{np} / \mathrm{A}}\right)$ continued to increase with the quantity of particles in suspension. This effect was followed by the reduction of the incorporated particle size, as can be seen in Fig. 2 and Table 1, and shows a selective phenomenon of incorporation.
This selective phenomenon of incorporation can be explained based on the probability of mechanical interaction between the particles in suspension that leads to the cathode, and the particles ongoing incorporation. It should be considered that just one particle is completely incorporated in the metallic matrix after a certain critical thickness of the deposit, when its ejection caused by arriving particles is no longer mechanically possible.

The time necessary for the definitive incorporation of one particle is, therefore, a function of the particle size, i.e., the bigger the particle size, the larger the time required to its definite incorporation into the metallic matrix [9].

Grosjean [27] studying the $\mathrm{SiC}$ incorporation (average size of $1 \mu \mathrm{m}$, and granulometric distribution between 0.3 and $1.5 \mu \mathrm{m}$ to $80 \%$ of the particles) in a NiP matrix obtained by autocatalytic (nickel electroless) reduction, observed a higher amount of incorporated particles with size between 0.3 and $0.9 \mu \mathrm{m}$, and the particles with higher size (over $3.9 \mu \mathrm{m}$ ) were not incorporated. Nevertheless, differently from the results presented in this work, this characteristic does not change as a function of the amount of particles in suspension; the author worked with low concentrations of $\mathrm{SiC}$ in suspension (from $5 \mathrm{~g}$ $\mathrm{L}^{-1}$ to $30 \mathrm{~g} \mathrm{~L}^{-1}$ ) and used experimental conditions different from those used in the present work.

The particles concentration increase in suspension, increases the probability of ejection of the higher particles during the incorporation process, as a result of the impacts caused by particles in suspension. This effect reduces, therefore, the probability of incorporation of bigger particles comparatively to smaller ones, which are more rapidly incorporated and over which the impact is less effective. Because of that, the incorporation of smaller particles is more favorable [9].

\subsection{Effect of anionic surfactant addition}

This work studied the effect of the surfactant addition over the $\mathrm{SiC}$ incorporation, in the electrolyte used to obtain NiP-SiC composite coatings.

From the micrographs obtained by SEM (Fig. 3), and from the counting of particles (Fig. 4) it can be observed that surfactant addition decreases the amount of incorporated $\mathrm{SiC}$

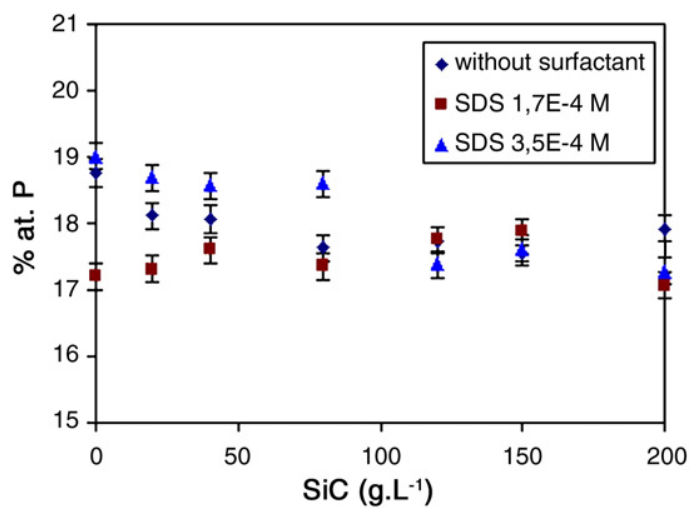

Fig. 5. Variation of \%at $\mathrm{P}$ as function of the $\mathrm{SiC}$ concentration in suspension and for different SDS concentrations. 


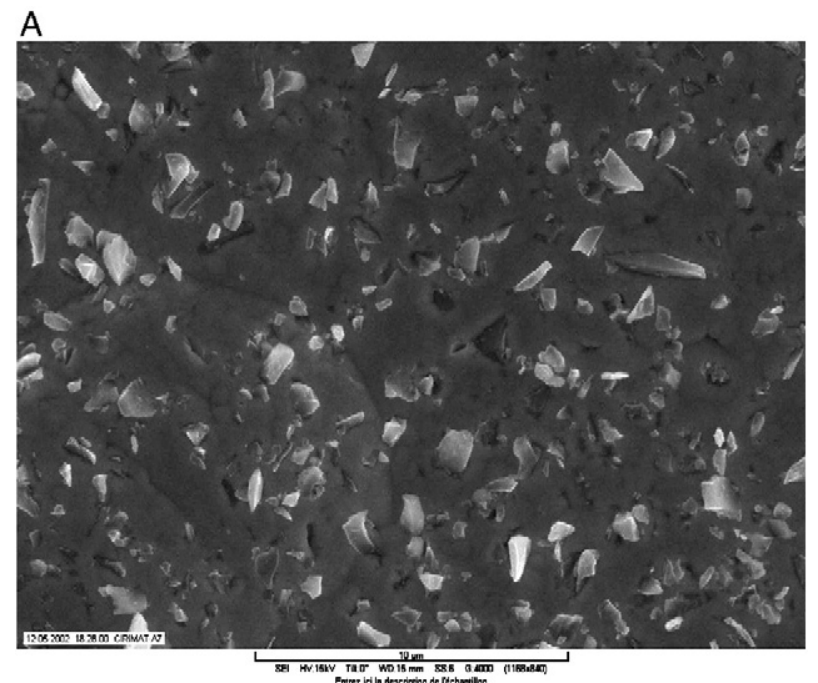

B

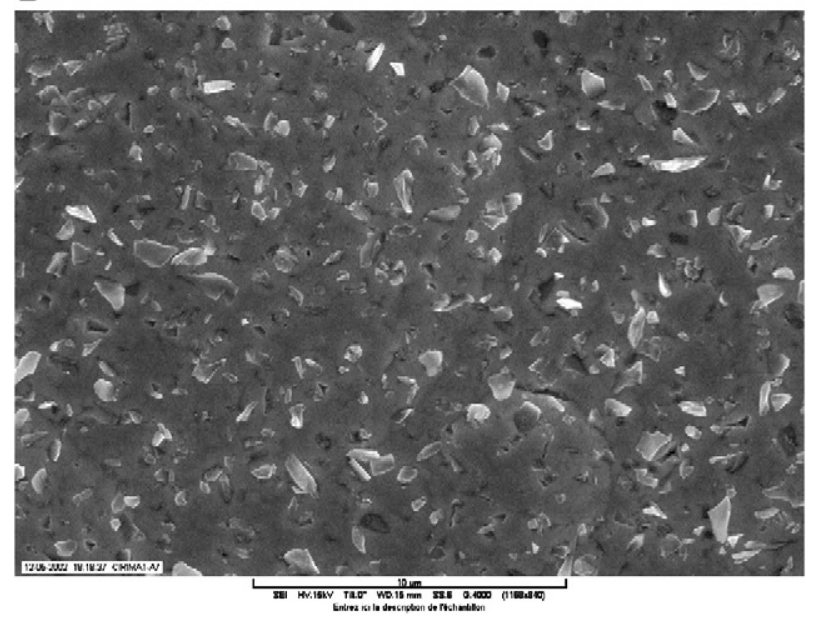

Fig. 6. Micrographs obtained by SEM of the composite coatings: A) $120 \mathrm{~g} \mathrm{~L}^{-1}$ $\mathrm{SiC}$ and 3.5.10 $0^{-4} \mathrm{M}$ CTAHS; B) $200 \mathrm{~g} \mathrm{~L}^{-1} \mathrm{SiC}$ and 3.5. $10^{-4} \mathrm{M}$ CTAHS

into the composite coatings, comparatively to those obtained without the SDS addition.

Particle count allows drawing the variation of the incorporation rate as a result of the $\mathrm{SiC}$ concentration in suspension, to different SDS concentration, as shown in Fig. 4. The relationship between the increase in SDS concentration in the electrolyte and the amount of incorporated $\mathrm{SiC}$ particles in the metallic matrix was not observed.

Two hypotheses can be proposed to explain the decrease in amount of incorporated particles into the NiP-SiC composite coating, obtained from an electrolyte with SDS.

The first hypothesis concerns the fact that surfactant addition decreases the surface tension as was observed in past studies $[28,29]$. Some authors observed that particle incorporation is influenced by a force balance that acts over the particle [30]. In this case, SDS addition could have acted on the particle adherence force on the cathode (considering that the surfactant can be adsorbed on the particles and even on the cathodes surface), therefore decreasing its incorporation degree.

The second hypothesis is based on the fact that the surfactant adsorption on the particles surface can even change their hydrophobic behavior. The well known surfactants usually adsorb themselves on the particle with their hydrophobic part, thus becoming the hydrophilic particle due to the surfactant layer which is adsorbed. Silicon-carbide ( $\mathrm{SiC})$ is usually hydrophobic, and when it appears this way, it is favorably incorporated. Surfactant addition, independent of its charge, can change the hydrophobic behavior of the particle. It is necessary to consider that a hydrophilic particle, in order to incorporate, must turn aside, avoiding the water molecules that are adsorbed in the surface, while the hydrophobic particle does not have that problem. The results observed by Tervieza et al. [31] showed the co-deposition of hidropobic silica from electrolytes containing $10^{-4} \mathrm{M}$ CTAHS, while particle incorporation was not noticed from electrolytes containing $10^{-4} \mathrm{M}$ SDS. This result suggests that the surfactants can modify the surface properties of both particles and electrode. However, in the present work, it seems that the co-deposition of the $\mathrm{SiC}$ particles is not controlled by the charge polarity presented in its surface, but rather by the hydrophobic degree.

Another effect was observed when the coatings were obtained from a plating bath with SDS added. As shown in Fig. 3 and Table 1, with surfactant addition the size of the incorporated particles raises, while the amount decreases, comparatively to the composite NiP-SiC coatings obtained from a bath without the additives addition, which indicates a phenomenon of selectivity.

This could be explained by the fact that, to those larger particles, the hydrodynamic effect is more important than interface effects [32]. Thus, the larger particles could not be completely covered by the surfactant, while to smaller particles the full cover up of the surface becomes easier. Therefore, the adsorbed surfactant over the smaller particles covers its surface completely, making it hydrophilic and complicating its incorporation. To those larger particles, there still is the possibility of adsorbing initially into the cathode by small areas that are free from the adsorbed surfactant. The surfactant presence can even cause flotation of smaller particles [33], thus leaving just the larger ones in suspension.

SDS addition does not change the phosphorus concentration in the deposit, as shown in Fig. 5, indicating, therefore, that it does not have remarkable influence over the obtaining process and over the NiP metallic matrix composition.

Table 2

Incorporated particle number $/ \mu \mathrm{m}^{2}$ evolution

\begin{tabular}{|c|c|c|c|c|}
\hline \multirow{3}{*}{$\begin{array}{l}\mathrm{SiC} \text { concentration } \\
\text { in the electrolyte } \\
\left(\mathrm{g} \mathrm{L}^{-1}\right)\end{array}$} & \multicolumn{4}{|c|}{ Incorporated particle number $/ \mu \mathrm{m}^{2}\left(\alpha_{\mathrm{np} / \mathrm{A}}\right)$} \\
\hline & \multirow{2}{*}{$\begin{array}{l}\text { Without } \\
\text { surfactant }\end{array}$} & \multicolumn{2}{|l|}{ SDS } & \multirow{2}{*}{$\frac{\text { CTAHS }}{3.5 \cdot 10^{-4} \mathrm{M}}$} \\
\hline & & $1.7 .10^{-4} \mathrm{M}$ & $3.5 \cdot 10^{-4} \mathrm{M}$ & \\
\hline 0 & 0 & - & - & - \\
\hline 20 & 0.62 & - & - & - \\
\hline 40 & 0.82 & - & - & - \\
\hline 80 & 0.84 & 0.39 & 0.34 & 0.44 \\
\hline 120 & 0.99 & 0.58 & 0.39 & 0.75 \\
\hline 150 & 1.12 & 0.67 & 0.60 & - \\
\hline 200 & 1.44 & 0.73 & 0.70 & 0.84 \\
\hline
\end{tabular}

It is evaluated as function of the $\mathrm{SiC}$ concentration in suspension, and as function of different SDS and CTAHS concentrations in the electrolyte. 


\subsection{Effect of the cationic surfactant addition}

In order to verify the charge influence of the surfactant over the amount of incorporated particles composite coatings were elaborated with the cationic surfactant CTAHS.

As was seen in past studies, the addition of SDS, which is an anionic surfactant, caused a decrease in the amount of particles incorporated into the metallic matrix, while obtaining NiP-SiC composite coating.

Terzieva [31], recently, verified in a study on the codeposition of silica (hydrophobic and hydrophilic) and copper that, from a plating bath of acid copper sulfate, hydrophobic silica was co-deposited in the presence of CTAHS, and was not deposited in the presence of SDS. That difference suggests that surfactants can also modify the electrode surface, having an important influence on particle incorporation.

The results showed that, regarding coatings obtained from an electrolyte without surfactant (Fig. 2), the electrodeposits obtained with 3.5.10 ${ }^{-4} \mathrm{M}$ CTAHS (Fig. 6) presented a decrease in the amount of incorporated particles, followed by the increase of its sizes (Tables 1 and 2), which are the same characteristics observed in composite coatings with SDS suspensions. It suggests that these phenomena are associated to surfactant presence and not to its charge.

Nevertheless, comparing the incorporated particle number in the composite coatings obtained from a suspension with 3.5.10 ${ }^{-4} \mathrm{M} \mathrm{SDS}$, it can be observed that, in the presence of cationic surfactant, $\alpha_{\mathrm{np} / \mathrm{A}}$ values are higher, thus indicating that surfactants charge exerts influence over the amount of incorporated particles, in agreement with results obtained by Terzieva et al [31]. However, comparative to non-surfactant obtained deposit, even cationic surfactant addition causes decrease in the amount of incorporated particle, which in this case could be associated to other factors, such as the decrease in surface tension that, as was already mentioned, can cause changes in the cathode surface, influencing the forces that act over the particle at the moment of incorporation.

\section{Conclusions}

Incorporation of particles from a suspension with well known concentration defined into particles with average size of $600 \mathrm{~nm}$ and large granulometric distribution may lead to composites whose amount and incorporated particle size differs as a result of elaboration conditions.

Result interpretation can also be different as function of how to evaluate the incorporation rate. Thus, in the experimental conditions used, as soon as the particle concentration increases, a limit value of the incorporation rate appears when it is evaluated as function of the incorporated particle volume $\left(\alpha_{\mathrm{v}}\right)$, while it does not occur when the evaluation is made based on the number of particles per area unit $\left(\alpha_{\mathrm{np} / \mathrm{A}}\right)$.

The addition of surfactants SDS (anionic) and CTAHS (cationic) has influence over the incorporation rate of the particles into the metallic matrix. Decrease of the amount of particles incorporated was observed, associated with the increase in its sizes, which indicates a selective process of particle incorporation due to the addition of surfactant in the suspension utilized to composite coatings elaboration. It suggests that these phenomena are mainly associated to surfactants presence and are practically independent from its charge.

\section{Acknowledgements}

The authors wish to thank CAPES, CNPq; FAPERGS and CNRS

\section{References}

[1] Official Journal of The European Union. Directive 2002/96/Ec, 2003.

[2] R.K. Guffie, The Handbook of Hard Chromium Plating Ohio, 1986, p. 192.

[3] S.I.L. Diaz, PhD thesis, UFRGS, Porto Alegre, Brazil, 2003.

[4] J.W. Graydon, D.W. Kirk, J. Electrochem. Soc. 137 (7) (1990) 2061.

[5] M.J. Bhagwat, J.P. Celis, J.R. Ross, Trans. Inst. Met. Finish. 61 (1983) 72.

[6] Q. Hong, G. Yao, Met. Finish. 96 (10) (1998) 16.

[7] X. Hu, C. Daí, D. Wang, Plating Surf. Finish. (Mar 1997) 51.

[8] A. Hovestad, L.J.J. Jansem, J. Appl. Electrochem. 25 (1995) 519.

[9] J.P. Celis, J.R. Roos, C. Buelens, J. Electrochem. Soc. 134 (6) (1987) 1402.

[10] A.M. Bernardes, R.F. Dalla Costa, V.L.V. Fallavena, M.A.S. Rodriguês, M.D Trevisan, J. Zoppas Ferreira, Met. Finish. E 114 (November 2000) 52.

[11] S. Vaillant, PhD thesis, Université Paul Sabatier, Toulouse, France, 2002, 170p.

[12] S. Vaillant, L. Datas, J.-P. Bonino, Mater. Tech. 11-12 (2001) 47.

[13] J.R. Roos, J.P. Celis, J. Fransaer, C. Buelens, JOM 11 (1990) 60.

[14] D.T. Gawne, U. Ma, Wear 129 (1989) 123.

[15] I. Apachitei, F.D. Tichelaar, J. Duszczzyk, L. Katgerman, Surf. Coat. Technol. 149 (2002) 263.

[16] I.R. Aslanyan, J.-P. Bonino, J.-P. Celis, Surf. Coat. Technol. 200 (2006) 2909.

[17] C.F. Malfatti, J. Zoppas Ferreira, C.B. Santos, B.V. Souza, E.P. Fallavena, S. Vaillant, J.-P. Bonino, Corros. Sci. 47 (2005) 567.

[18] I. Garcia, A. Conde, G. Langelaan, J. Fransear, J.P. Celis, Corros. Sci. V45 (N. 6) (2003) 1173.

[19] H. Matsuda, et al., Trans. Inst. Met. Finish. 73V (n. 1) (1995) 16.

[20] V. Terzieva, J. Fransaer, J.P. Celis, J. Electrochem. Soc. v.147 (n.1) (2000) 198.

[21] A. Hovestad, R.J.C.H.L Heesen, J. Jansen, J. Appl. Elecrochem. 29 (1999) 331-338.

[22] X. Hu, C. Daí, D. Wang, Plating Surf. Finish. (Mar 1997) 51.

[23] A. Brenner, Electrodeposition of Alloys: Principles and Practice, academy Press, New York, 1963, p. 457.

[24] A. Lavanant, PhD thesis, Université Pierre et Marie Curie Paris 6, France, 1991, 176p.

[25] S.H. Yeh, C.C. Wan, Plating Surf. Finish. (March 1997) 54.

[26] S. Shawki, Z.A. Hamid, Anti-Corros. Methods Mater. 44 (3) (1997) 178.

[27] A. Grosjean, PhD thesis, I'u. F.R. Des Sciences et Tecniques de Université de Franche-Comté, France, 1998, 215p.

[28] F.A. Lowenheim, Modern Electroplating, 3. ed., John Wiley, 1974, 80 pp.

[29] C.F. Malfatti, J. Zoppas Ferreira, S. Vaillant, P. Bacchin, J.-P. Bonino, XI Ebrats 2003, São Paulo - Brasil, 2003.

[30] M.J. Bragwat, J.P. Celis, J.R. Roos, Trans. Inst. Met. Finish. 134 (6) (1987) 1402.

[31] V. Terzieva, J. Fransaer, J.P. Celis, J. Electrochem. Soc. 147 (1) (2000) 198.

[32] J. Fransaer, J.P. Celis, J.R. Roos, J. Electrochem. Soc. 139 (2) (1992) 413.

[33] M. Daoud, C. Willians, La Juste Argile, Les Éditions des Physique, France, vol. 1v, 1995, $327 \mathrm{pp}$. 